receptor and the $\beta$-adrenergic receptors, and their relation to adenylcyclase, through opiate and prostaglandin receptors, to the inhibition of adenylcyclase in Escherichia coli by glucose. Interesting though the latter effect is in relation to catabolite regulation in microbes, its relevance to the adenylcyclase system of animals is questionable.

Throughout one is struck by the careful balance achieved in each section, which reflects as much credit on the Chairman of the Program Committee (Purnell W. Choppin), as on the two editors concerned with the production of the book. It is becoming increasingly apparent that no biochemist, whatever his field, can afford to ignore the subject of membranes. This account of the most important components of surface membranes-the cellular receptors-will be appreciated by a wide audience. The financial contribution of Miles Laboratories towards the symposium was worth while and timely. Perhaps they might be encouraged to extend their patronage of subsequent symposia to underwriting part of the production costs. In that case, the scientific community at large will benefit as much from their generosity as the participants of the symposium.

C. A. Pasternak

\title{
Acute diarrhoea in childhood
}

Edited by Katherine Elliott and Julie Knight. 1976. Ciba Foundation Symp. no. 42 (new series). Amsterdam, Oxford and New York: Elsevier. Pp. 375 . US \$26.95.

The recent explosion of knowledge of infantile gastro-enteritis has several sources, notably in the pathophysiology of cholera, in the aetiology of diarrhoea of domestic animals, in viral causes of diarrhoea and in mucosal defence-mechanisms. The Ciba Foundation rightly judged the time ripe for one of its famous symposia, held in London in October 1975 and now published as a book full of good things. The largest emphasis is on cholera and ion transport (four papers) and on viral gastro-enteritis (five papers). Many other aspects are discussed, and the proceedings would almost serve as a general account of modern views on gastro-enteritis but for one curious omission; although much mention is made of Escherichia coli infection there is no specific discussion of the significance of enterotoxin production by $E$. coli in human diarrhoeal disease. The individual papers are nearly all excellent, authoritative and up to date, and the discussions largely avoid the embarrassing banality which lively encounters at a meeting so often assume in cold print. Moreover, the editors avoid a common annoyance of printed discussions by including references to the discussion points as well as the main texts. It may be invidious to pick out one paper from so many good ones, but the closing contribution from Jon Rohde, called "Taking science where the diarrhoea is", does deserve special mention. While acknowledging the major success by which fundamental transport studies led to the use of oral glucose-electrolyte solution in the field, he shows how many gaps there are between ideas and their application. A broad ecological and sociological view is essential if research in diarrhoeal disease is to lead to improved child health in the poor countries of the world.

H. P. LAMBerT

The role of culture collections in the era of molecular biology

Edited by Rita R. Colwell. 1976. Washington D.C.: American Society for Microbiology. Pp. vii and 76 . US $\$ 12$.

Despite its rather misleading title, this slim volume is not a textbook but thirteen contributions to a souvenir volume to celebrate the 50th Anniversary of the American Type Culture Collection (ATCC) held in September 1975. They are a stimulating and speculative set of essays; some deal directly with culture collections and others more remotely.

An entertaining foreword by S. T. Cowan is followed by a brief account of the history of the ATCC by its Director, Richard Donovick. C. Lamanna stresses the museum aspect 